\title{
Factors Affecting the Morbidity and Mortality of Malignancy Patients Admitted to the Emergency Department
}

\author{
Acil Servise Başvuran Malignite Hastalarının Morbidite ve Mortalitelerini Etkileyen Faktörler
}

\begin{abstract}
Tokocin $\mathrm{O}^{1}$, Cakmak F², Ipekci A², Tihan $\mathrm{DN}^{3}$, Ceylan $\mathrm{D}^{4}$, Sutasir $\mathrm{MN}^{5}$, Emir $\mathrm{C}^{6}$, Dandin $\mathrm{O}^{7}$, Tokocin $\mathrm{M}^{8}$, Ikizceli $\mathrm{I}^{2}$
1-Department of Emergency Medicine, Kagıthane State Hospital, Istanbul, Turkey, 2-Department of Emergency Medicine, Cerrahpasa Faculty of Medicine, Istanbul University Cerrahpasa, Istanbul, Turkey, 3-Department of General Surgery, Bursa Special Training and Research Hospital, Bursa, Turkey, 4-Department of Emergency Medicine, Hatay Dortyol State Hospital, Hatay Turkey, 5-Department of Emergency Medicine, Sisli Etfal Training and Research Hospital, Istanbul, Turkey, 6-Department of Emergency Medicine, Koc University, Istanbul, Turkey, 7-Department of General Surgery, Bursa Military Hospital, Bursa, Turkey 8-Department of General Surgery, Bagcilar Training and Research Hospital, Istanbul, Turkey,
\end{abstract}

\begin{abstract}
Objectives: The objective of this study is to identify the clinical characteristics and the factors affecting the morbidity and mortality of the patients with malignancy and to increase the quality of care and raise awareness of rapid targeted-therapy in the emergency department.

Materials and Methods: In our study, cancer patients 18 years of age and older who presented to the emergency department of a university hospital were evaluated prospectively. Patients' demographics, vital signs, characteristics associated with malignancy, examinations performed, and their results, treatments, and length of stay were evaluated.

Results: A total of 1283 patients and 1522 presentations were recorded. 51.99\% of the patients were male, and $48.01 \%$ were female. The overall mean age was $63.05 \pm 14.08$. The most prevalent symptom was dyspnea (17.94\%), and the most common type of cancer was lung cancer (16.23\%). In male patients, the most prevalent complaint was fever, and the most common type of cancer was lung cancer (34.63\%). In female patients, the most prevalent complaint was dyspnea, and the most common type of cancer was breast cancer (35.25\%). The influence of MAP, pulse, Hb levels, uremia, and hypoalbuminemia on mortality and ICU admission was significant. Overall, $41.46 \%$ of the patients were hospitalized, and $1.05 \%$ of the patients died. The average length of stay was $4.64 \pm 6.73$ days.

Conclusion: Patients with malignancy constitute a significant portion of emergency department admissions. Promoting the emergency physicians' insight into and experience on oncological emergencies would contribute to decreasing the mortality and morbidity of these patients.

ÖZET

Amaç: Çalışmada acil servis başvuran malignite hastalarının klinik karakteristik özelliklerini, morbidite ve mortalitelerine etki eden faktörleri inceleyerek hastaların bakım kalitesini ve hedefe yönelik hızl tedavi bilincini artırmayı amaçladık.

Gereç ve Yöntem: Üniversite Hastanesi Acil Tip Kliniğine 06.11.2014-06.05.2015 tarihleri arasinda başvuran, 18 yas ve üzeri kanser hastaları prospektif olarak incelendi. Hastalartn demografik özellikleri, vital bulguları, maligniteleri ile ilgili özellikler, yapılan tetkikler ve sonuçları, tedaviler ve acil serviste yatış süreleri değerlendirildi.

Bulgular: Toplam 1283 hastanın, 1522 bassvuru yaptığ tespit edildi. Hastaların \%51,99'u erkek (ortalama

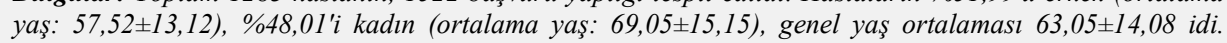
Nefes darliğ $(\% 17,94)$ en sık başvuru şikayeti olup, en sik rastlanan kanser türü akciğer kanseri $(\% 16,23)$ idi. Erkeklerde en sik başvuru nedeni ateş, en slk kanser türü akciğer kanseri (\%34,63); kadınlarda en sik başvuru şikayeti nefes darlığ, en sik kanser tipi meme kanseri olarak saptandı $(\% 35,25)$. Hastaların $\% 64$ 'ünde uzak metastaz mevcuttu. Ortalama arteriyal basincinin, nabiz dakika saylsinin, hemoglobin düzeyinin, üremi ve hipoalbümineminin, mortalite ve yoğun bakım yatış oranları üzerinde anlaml etkisi saptandl. Hastalarm \%41,46'sl herhangi bir servise yatırllurken, \%1,05'i kaybedildi. Hastaneye yatısıl

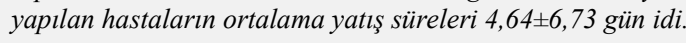

Sonuç: Malignite hastaları acil servise başvuran hastaların önemli bir kismını oluşturmaktadır. Acil servis hekimlerinin onkolojik aciller konusunda yeterli bilgi, deneyim ve tecrübe edinmeleri, bu hastalartn mortalite ve morbidite oranlarını azaltacaktır.
\end{abstract}

Key Words:

Emergency Medicine,

Malignancy,

Mortality,

Morbidity,

Complication.

Anahtar Kelimeler:

Acil Tip,

Malignite,

Mortalite,

Morbidite,

Komplikasyon.

\section{INTRODUCTION}

Cancer is one of the most common causes of death all over the world. The data from 2009 published by the Public Health Agency of Turkey clarified that the most common type of cancer in females is breast cancer (23.4\%), while the most common type of cancer in males is lung-bronchus cancer (25.7\%). According to the ICD-10 main diagnosis criteria, $3.9 \%$ of the hospitalizations in 2013 were due to diagnoses of neoplasms (1).

\section{Received: 13.09 .2019}

Correspondence: Fatih Cakmak, MD. İstanbul Üniversitesi Tıp Fakültesi Yerleşkesi Kocamustafapaşa Cd. No: 53 Cerrahpaşa 34098 Fatih/İstanbul, Turkey. E-mail: fatih.cakmak@istanbul.edu.tr Phone: +90 (532) 6539947

Cite this article as: Tokocin O, Cakmak F, Ipekci A, Tihan DN, Ceylan D, Sutasir MN, et al. Factors Affecting the Morbidity and Mortality of Malignancy Patients Presenting to the Emergency Department. Phnx Med J. 2019; 1(1): 8-14. 
Because of the increase in public awareness of cancer, as well as early diagnosis and treatment facilities, the number of diagnosed cancer cases rises. These factors cause an extension in the follow-up period and an increase in the number of emergency department (ED) admissions (2). Consequently, cancer patients are a patient group that significantly increases the workload of ED and has psychosocial issues (3). In cancer patients, the frequency of presentation to the ED increases in the last six months of life due to decreased functional capacity, severe uncontrolled pain, and confusion (4).

Cancer patients present to the ED with various clinical conditions and complications. The most common reasons of ED presentations of cancer patients include metabolic complications, respiratory complications, hematologic complications, infections associated with febrile neutropenia and suppressed immunity, gastrointestinal hemorrhage and tumor-induced acute mechanical intestinal obstruction, neurological complications associated with spinal cord compression and brain metastasis; and complaints of pain due to such complications (5-9). If familiarization with cancer patients admitted to the emergency department, a thorough assessment of their clinical signs, and early recognition of the possible complications is combined with an effective and rapid treatment, life expectancy and quality of these patients will improve. This study analyses the demographics, complaints, symptoms, length of stay, and the diagnoses of the cancer patients who admitted to the emergency department due to any reason other than trauma and aims to promote the emergency physicians' insight into and skills on oncological emergencies and to emphasize the importance of planning a rapid and effective treatment.

\section{MATERIALS AND METHODS}

This study was scheduled as a prospective observational clinical study after obtaining approval of the Ethics Committee. The collected data were from patients who admitted to the emergency department of a university hospital, which has an annual adult patient number of 59.787, between November 6, 2014, and May 6, 2015, were evaluated.

Patients age 18 years and older, who had a previous diagnosis of cancer or who were diagnosed with cancer during their hospitalization in the emergency department were included in the study. Cancer patients who presented with trauma, those younger than 18 years of age, those who did not agree to complete the study form or those who were in cardiopulmonary arrest at the time when they are brought to the emergency department were excluded from the study.

Presenting complaints reported by the patient or their relatives, demographics and blood pressure, pulse, temperature, biochemical test results, imaging results, microbiological tests, diagnosis, treatment, length of stay, and whether they were referred to another department or died were recorded.

\section{Statistical Analysis}

All data were entered into the computer system using Microsoft Excel for Mac 2011, and statistical analyses were conducted using IBM SPSS Statistics for Mac 22.0 (SPSS Inc., Chicago, USA). As statistical analysis, descriptive statistics (mean \pm standard derivation for parametric data, and median and minimum-maximum values, as well as percentage distribution, for non-parametric data) were used. Chi-square test was used to assess the qualitative variables between the groups, and Student-T test and Mann Whitney U test was used to determine the quantitative variables between the groups. The statistical significance level was taken as $\mathrm{p}<0.05$ for all analyses.

\section{RESULTS}

1522 (4.98\%) patients who had a previous diagnosis of cancer or who were newly diagnosed with cancer out of 30.538 patients admitted to the emergency department were analyzed prospectively. 239 presentations out of 1522 were repeated presentations. After the repeated presentations were adjusted, the net number of presenting patients was 1238 . Distribution of the admissions according to age intervals, as shown in table 1. Demographics were analyzed based on the net amount of patients.

Table1: Distribution of the admissions according to age intervals

\begin{tabular}{lcr}
\hline $\begin{array}{l}\text { Age } \\
\text { intervals }\end{array}$ & $\begin{array}{c}\text { Total number of } \\
\text { admission }\end{array}$ & \% \\
\hline $18-19$ & 2 & 0,16 \\
$20-29$ & 32 & 2,49 \\
$30-39$ & 82 & 6,39 \\
$40-49$ & 156 & 12,16 \\
$50-59$ & 364 & 28,37 \\
$60-69$ & 388 & 30,24 \\
$70+$ & 259 & 20,19 \\
\hline Total & $\mathbf{1 2 8 3}$ & $\mathbf{1 0 0}$ \\
\hline
\end{tabular}

In our study, 667 of the 1283 patients included in the study were male (51.99\%), and 616 were female (48.01\%). The mean age was $57.52 \pm 13.12$ in male patients and $69.05 \pm 15.15$ in female patients. The overall mean age was $63.05 \pm 14.08$.

The five most prevalent presenting complaints were as follows: dyspnea 273 (17.94\%), fever-chillstremor 231 (15.18\%), fatigue 213 (13.99\%), abdominal pain 112 (7.36\%), nausea-vomiting 102 (6.70\%). 997 (77.71\%) of the presenting patients had solid tumors, and $286 \quad$ (22.29\%) had hematologic tumors (Table 2). 
Phnx Med J. November, Volume 1 No 1

Tablo 2. Distribution of primary complaints at admission

\begin{tabular}{|c|c|c|c|c|c|c|}
\hline Signs and symptoms & $\mathbf{n}$ & (\%) & Female & $(\%)$ & $\begin{array}{l}\text { Mal } \\
\text { e }\end{array}$ & $(\%)$ \\
\hline Dyspnea & 273 & 17,94 & 129 & 17,53 & 144 & 18,32 \\
\hline Fever and chills & 231 & 15,18 & 56 & 7,61 & 175 & 22,26 \\
\hline Debility & 213 & 13,99 & 121 & 16,44 & 92 & 11,70 \\
\hline Abdominal pain & 112 & 7,36 & 68 & 9,24 & 44 & 5,6 \\
\hline Nausea and vomiting & 102 & 6,70 & 89 & 12,09 & 13 & 1,65 \\
\hline Pain $^{\text {a) }}$ & 98 & 6,44 & 38 & 5,16 & 60 & 7,63 \\
\hline Diarrhea & 57 & 3,75 & 7 & 0,95 & 50 & 6,36 \\
\hline Confusion & 57 & 3,75 & 21 & 2,85 & 36 & 4,58 \\
\hline Pain during urination & 54 & 3,55 & 27 & 3,67 & 27 & 3,44 \\
\hline Headache & 48 & 3,15 & 38 & 5,16 & 10 & 1,27 \\
\hline Swelling in the lower limbs & 39 & 2,56 & 30 & 4,08 & 9 & 1,15 \\
\hline Palpitation & 37 & 2,43 & 28 & 3,80 & 9 & 1,15 \\
\hline Hemoptysis & 29 & 1,91 & 2 & 0,27 & 27 & 3,44 \\
\hline Hematuria & 25 & 1,64 & 0 & 0 & 25 & 3,18 \\
\hline Inability to urinate & 22 & 1,45 & 22 & 2,99 & 0 & 0 \\
\hline Constipation & 19 & 1,25 & 10 & 1,36 & 9 & 1,15 \\
\hline Chest pain & 18 & 1,18 & 9 & 1,22 & 9 & 1,15 \\
\hline Epilepsia & 17 & 1,12 & 9 & 1,22 & 8 & 1,02 \\
\hline Hematemesis & 13 & 0,85 & 0 & 0 & 13 & 1,65 \\
\hline Dizziness & 12 & 0,79 & 0 & 0 & 12 & 1,53 \\
\hline Abdominal swelling & 12 & 0,79 & 12 & 1,63 & 0 & 0 \\
\hline Others $^{\mathrm{b})}$ & 34 & 2,24 & 20 & 2,73 & 14 & 1,78 \\
\hline Total $* *$ & 1522 & 100 & 736 & 100 & 786 & 100 \\
\hline
\end{tabular}

The two most common type of cancer was lungbronchus cancer ( $n=247 ; 16.23 \%)$ and breast cancer $(n=217 ; 14.26 \%)$. The most prevalent type of cancer was breast cancer $(n=217 ; 35.23 \%)$ in females and lung cancer $(n=231 ; 34.63 \%)$ in males. 821 (64\%) of the patients had distant organ metastasis at the time of the presentation (Table 3).

115 patients $(7.55 \%)$ had fever (body temperature $\left.>37.5^{\circ} \mathrm{C}\right), 512$ patients $(33.64 \%)$ had subfebrile temperature $\left(37.6^{\circ} \mathrm{C}>\right.$ body temperature $\left.>37^{\circ} \mathrm{C}\right)$, and 69 patients (4.53\%) had hypothermia (body temperature $<35.5^{\circ} \mathrm{C}$ ) at the time of the presentation. In 330 patients $(21.68 \%)$, the mean arterial pressure (MAP) was low $(<70 \mathrm{mmHg})$. One hundred thirty-three patients (8.73\%) had hypertension (systolic blood pressure $>120 \mathrm{mmHg}$ ) at the time of the presentation. The initial measurement of pulse (BPM) in the emergency department revealed that 24 patients $(1.58 \%)$ had bradycardia (BPM <60), and 395 patients $(29.95 \%)$ had tachycardia $(\mathrm{BPM}>100)$. The most prevalent electrolyte abnormality in the patients admitted to the emergency department was hypochloremia with 650 patients (42.71\%), the most prevalent biochemical abnormality was uremia with 604 patients (39.68\%), and the most prevalent blood count parameter abnormality was anemia with 987 patients (64.85\%). Additionally, 69 patients (6.04\%) had absolute neutropenia, and 520 patients (34.17\%) had hypoalbuminemia. Patient vital signs and blood parameters and comparison of these values between non-survival and intensive care and other patients were shown in table 4 .

The most prevalent final diagnoses made upon the examination of the malignancy patients in the emergency department were as follows: pneumonia $(n=319 ; 20.96 \%)$, malignancy-related pain $(n=276$; $18.13 \%)$ and electrolyte abnormality $(n=276$; $18.13 \%$ ) (Table 5).

$71,95 \%$ of the patients were treated in and discharged from the ED. The average length of stay of the patients in the ED was $4.64 \pm 6.73$ days, and the average length of stay until being admitted to the hospital 3.04 \pm 1.91 days. 
Tablo 3. Distribution of the cancer type

\begin{tabular}{|c|c|c|c|c|c|c|}
\hline \multirow{2}{*}{ Type of malignancy } & \multicolumn{2}{|c|}{ Overall patients } & \multicolumn{2}{|c|}{ Female Patients } & \multicolumn{2}{|c|}{ Male patients } \\
\hline & $\mathbf{n}$ & $(\%)$ & $\mathbf{N}$ & $(\%)$ & $\mathbf{N}$ & $(\%)$ \\
\hline Lung-bronchial & 247 & 19,25 & 16 & 2,50 & 231 & 34,63 \\
\hline Breast & 217 & 16,91 & 217 & 35,23 & 0 & 0 \\
\hline Lymphoma & 119 & 9,28 & 28 & 4,55 & 91 & 13,64 \\
\hline Leukemia & 119 & 9,28 & 62 & 10,06 & 57 & 8,55 \\
\hline Colorectal & 104 & 8,11 & 68 & 10,04 & 36 & 5,40 \\
\hline Stomach & 55 & 4,29 & 22 & 3,57 & 33 & 4,95 \\
\hline Over & 50 & 3,90 & 50 & 8,12 & 0 & 0 \\
\hline Brain & 48 & 3,74 & 11 & 1,79 & 37 & 5,55 \\
\hline Multiple Myeloma & 48 & 3,74 & 19 & 3,08 & 29 & 4,35 \\
\hline Liver & 45 & 3,51 & 22 & 3,57 & 23 & 3,45 \\
\hline Prostate & 44 & 3,43 & 0 & 0 & 44 & 6,60 \\
\hline Pancreas & 34 & 2,65 & 12 & 1,95 & 22 & 3,30 \\
\hline Cervix & 31 & 2,42 & 31 & 5,03 & 0 & 0 \\
\hline Thyroid & 27 & 2,10 & 25 & 4,06 & 2 & 0,30 \\
\hline Endometrium & 23 & 1,79 & 23 & 3,73 & 0 & 0,00 \\
\hline Bladder & 21 & 1,64 & 2 & 0,32 & 19 & 2,85 \\
\hline Mesothelioma & 14 & 1,09 & 2 & 0,32 & 12 & 1,80 \\
\hline Other $^{\mathrm{a})}$ & 28 & 2,19 & 5 & 0,81 & 23 & 3,45 \\
\hline New Diagnosis & 9 & 0,70 & 1 & 0,16 & 8 & 1,20 \\
\hline Total & 1283 & 100 & 616 & 100 & 667 & 100 \\
\hline
\end{tabular}

${ }^{a}$ Larynx, Intestine, Biliary, Neuroblastoma, Testis, Kaposi's Sarcoma, Malignant Melanoma

Table 4. Mean values and comparison of vital signs and blood parameters of the patients

\begin{tabular}{|c|c|c|c|}
\hline $\begin{array}{l}\text { Vital Sign / Blood } \\
\text { Parameters }\end{array}$ & Overall Patients & $\begin{array}{l}\text { Non-survival and Intensive } \\
\text { care }\end{array}$ & Other Patients \\
\hline Fewer $\left({ }^{\circ} \mathrm{C}\right)$ & $36,93 \pm 0,97$ & $36,05 \pm 0,96$ & $37,03 \pm 0,94$ \\
\hline SBP (mmHg)* & $113,14 \pm 27,63$ & $91,46 \pm 36,45$ & $115,2 \pm 20,01$ \\
\hline DBP (mmHg)* & $71,45 \pm 16,61$ & $58,15 \pm 23,64$ & $73,16 \pm 15,38$ \\
\hline MAP (mmHg)* & $84,92 \pm 19,76$ & $69,25 \pm 27,41$ & $73,16 \pm 15,38$ \\
\hline Pulse (dk)* & $90,46 \pm 19,68$ & $93,29 \pm 26,05$ & $89,32 \pm 18,28$ \\
\hline WBC $\left(10^{3} \mathrm{~mm}^{3}\right)$ & $10,05 \pm 12,66$ & $11,67 \pm 5,28$ & $9,64 \pm 13,6$ \\
\hline $\mathrm{Hb}(\mathrm{g} / \mathrm{dl})^{*}$ & $10,54 \pm 2,47$ & $8,7 \pm 4,25$ & $10,52 \pm 2,53$ \\
\hline Plt $\left(10^{3} \mathrm{~mm}^{3}\right)^{*}$ & $234,4 \pm 131,2$ & $346,53 \pm 183,04$ & $215,6 \pm 118,34$ \\
\hline $\mathrm{MCV}(\mathrm{fl})^{* *}$ & $84,63 \pm 7,27$ & $84,12 \pm 5,42$ & $85 \pm 2,28$ \\
\hline $\mathrm{MCH}(\mathrm{pg})$ & $29,08 \pm 2,92$ & $28,64 \pm 2,2$ & $29,28 \pm 2,9$ \\
\hline Neutrophil $\left(10^{3} \mathrm{~mm}^{3}\right)$ & $7,49 \pm 10,11$ & $7,19 \pm 5,4$ & $7,28 \pm 10,8$ \\
\hline Urea $(\mathrm{mg} / \mathrm{dl})^{*}$ & $61,58 \pm 65,27$ & $150,97 \pm 120,19$ & $52,06 \pm 49,79$ \\
\hline Creatinine (mg/dl)* & $1,42 \pm 1,67$ & $3,53 \pm 3,24$ & $1,18 \pm 1,18$ \\
\hline ALT (IU/L) & $29,85 \pm 26,6$ & $36,6 \pm 18$ & $29,32 \pm 26,27$ \\
\hline AST (IU/L) & $35,02 \pm 38,12$ & $42,83 \pm 25,55$ & $34,77 \pm 40,27$ \\
\hline Albumin (g/dl)* & $3,73 \pm 0,77$ & $3,12 \pm 0,52$ & $3,83 \pm 0,75$ \\
\hline CRP (mg/L)* & $70,96 \pm 97,97$ & $110,15 \pm 127,03$ & $62,92 \pm 92,78$ \\
\hline $\mathrm{Na}^{++}(\mathrm{mmol} / \mathrm{L})$ & $136,82 \pm 5,8$ & $131,93 \pm 7,04$ & $137,38 \pm 5,3$ \\
\hline $\mathrm{K}^{+}(\mathrm{mmol} / \mathrm{L})^{*}$ & $4,58 \pm 0,97$ & $5,89 \pm 1,43$ & $4,47 \pm 0,86$ \\
\hline $\mathrm{Ca}^{++}(\mathrm{mg} / \mathrm{dl})$ & $9,16 \pm 1,1$ & $8,64 \pm 0,88$ & $9,21 \pm 1,13$ \\
\hline $\mathrm{Cl}^{-}(\mathrm{mmol} / \mathrm{L})^{*}$ & $99,08 \pm 7,05$ & $93,15 \pm 9,43$ & $99,75 \pm 6,44$ \\
\hline
\end{tabular}

WBC, white blood count; Hb, hemoglobin; Plt, platelet count; MCV, mean corpuscular volume; $\mathrm{MCH}$, mean corpuscular hemoglobin; AST, aspartate aminotransferase; ALT, alanine aminotransferase; CRP, C-reactive protein; $\mathrm{Na}^{++}$, sodium; $\mathrm{K}^{+}$, potassium; $\mathrm{Ca}^{++}$, calcium; $\mathrm{Cl}^{-}$, chlorine; *, Stastically significant difference between non-survival and intensive care patients and other patients

\section{DISCUSSION}

The rate of ED presentation of patients with cancerrelated complications increases. The importance of ED for follow-up and treatment of cancer cases has been growing steadily. A study by Swenson et al.
(10) found the rate of ED presentation of cancer patients at $5 \%$. Similar studies conducted by several universities in Turkey reported that this rate varies between 0.98 and $5.2 \%(11,12)$. In our study, 
cancer patients made up $4.98 \%$ of the patients presented to the ED.

In a retrospective study in the ED, Yaylaci et al. (13) found that $55.7 \%$ of the patients were male, while $43.3 \%$ were female. Kerrouault et al. (14) reported that $65 \%$ of the patients were male. In our study, $51.99 \%$ of the patients were male, and $48.01 \%$ were female. We think that the prevalence of cancer is increased by the fact that negative factors such as smoking are more common among men in Turkey.

In our study, the overall mean age was $63.05 \pm 14.08$ years. The mean age of the male patients was $57.52 \pm 13.12$ years, and the mean age of the female patients was $69.05 \pm 15.15$ years. The most prevalently presenting patient group was mostly in the 6th decade, while the most prevalently presenting patient group among the repeated presentations was mostly in the 7th decade.

In their study, Bozdemir et al. (11) found that there were 245 cancer patients with 324 presentations out of 24903 presentations in 6 month period, and a review of recurrent presenting complaints revealed that the most prevalent complaints were pain and nausea-vomiting. In their study, Liaw et al. (15) found that the rate of repeated presentation to the emergency department was $79 \%$ among all patients, including those with malignancy.

In our study, 1283 patients presented 1522 times, 239 patients had repeated presentations. In the repeated presentations, the most prevalent type of malignancy was lymphoma, and the most prevalent presenting complaint was fever. We think that the increase in the incidence of cancer and other comorbid diseases due to advanced age may account for the increase in the mean age of the patients with repeated presentations. We also think that the high number of repeated presentations may be in connection with the emergency department services that are more easily and rapidly accessible compared to other department services, that ED provides non-stop healthcare, and that patients with a delay in hospital admission because of room unavailability are referred to ED.

In their study, Kılıçarslan et al. (16) reported that the most prevalent complaints of the patients presenting to the ED are chest pain, abdominal pain, dyspnea, and headache, respectively. Swenson et al. (10) reported that the rate of gastrointestinal system complaints was $48 \%$, and Kerrouault et al. (14) reported that the most prevalent complaint in the patients presenting to the emergency department was poor overall health,

In our study, the three most prevalent complaints of the patients presenting to the ED included dyspnea (17.94\%), fever (15.18\%), and fatigue (13.99\%). In our study, the most prevalent complaint among the overall presentations was dyspnea. We attribute this to the high prevalence of patients diagnosed with lung cancer. The second most prevalent presenting complaint was fever in our case series. In cancer patients, fever can occur due to malignancy or to
Table 5. Distribution of final diagnosis of the patients

\begin{tabular}{lll}
\hline Diagnosis & $\mathbf{N}$ & $\mathbf{\%}$ \\
\hline Pneumonia & 319 & 20,96 \\
\hline Pain-related to malignancy & 276 & 18,13 \\
\hline Electrolyte disturbance & 261 & 17,14 \\
\hline Sepsis & 227 & 14,91 \\
\hline Anemia & 194 & 12,75 \\
\hline Urinary tract infection & 120 & 7,88 \\
\hline Acute renal failure & 110 & 7,23 \\
\hline Respiratory insufficiency & 78 & 5,12 \\
\hline Constipation & 67 & 4,40 \\
\hline Febrile neutropenia & 64 & 4,20 \\
\hline $\begin{array}{l}\text { Vomiting related to } \\
\text { chemotherapy }\end{array}$ & 57 & 3,75 \\
\hline Acute gastroenteritis & 53 & 3,48 \\
\hline Brain edema & 38 & 2,50 \\
\hline $\begin{array}{l}\text { Edema related to } \\
\text { hypoalbuminemia }\end{array}$ & 36 & 2,37 \\
\hline Hypertension & 33 & 2,17 \\
\hline Thrombocytopenia & 32 & 2,10 \\
\hline Arrhythmia & 27 & 1,77 \\
\hline Hypoglycemia & 21 & 1,38 \\
\hline Pulmonary embolism & 21 & 1,38 \\
\hline $\begin{array}{l}\text { Upper respiratory tract } \\
\text { infection }\end{array}$ & 19 & 1,25 \\
\hline Deep venous thrombosis & 17 & 1,12 \\
\hline Gastrointestinal bleeding & 17 & 1,12 \\
\hline Othera) & 60 & 3,96 \\
\hline Total b) & $\mathbf{2 1 6 8}$ & $\mathbf{1 4 2 , 4 4}$ \\
\hline & & \\
\hline
\end{tabular}

${ }^{a}$ Soft tissue infection, brain metastasis, hydrocephaly, diabetes-related to steroid usage, spinal cord syndrome related to metastasis, Vena cava superior syndrome, choledocholithiasis, allergic reaction related to chemotherapy, shunt infection; ${ }^{\text {b) }}$ some patients got more than one diagnosis

increased frequency of infection during treatment because of immunosuppression (17).

The Turkish Cancer Statistics - data from 2009 -, published by the Ministry of Health in 2014, reported that in all age groups, the most common types of cancer in men are cancers of lung, prostate and bladder origin, respectively, while the most common types of cancer in women are those of breast, thyroid, and colorectal origin, respectively (1). Swenson et al. (10) reported that most prevalently presenting patients were those diagnosed with lung cancer and gastrointestinal system cancers $(16 \%)$.

Indeed, in our study, lung cancer (19.25\%) was the most prevalent presenting complaint followed by breast cancer (16.91\%). The third and the fourth most common presenting types were leukemia (9.28\%) and lymphoma (9.28\%). When malignancy diagnoses were analyzed by gender, it was found 
that the most common type of cancer in male patients were lung (34.63\%), lymphoma (13.36\%), and leukemia (8.55\%), while the most common types in female patients were breast cancer (35.23\%), leukemia (10.06\%), and colorectal cancer (10.04\%). The initial diagnosis of nine patients $(0.59 \%)$ in the study was made in the emergency department.

Metastasis was diagnosed at the time of the presentation in $64 \%$ of patients presenting to the emergency department in our study. When repeated presentations were analyzed separately, this rate was found to be higher (71.1\%). Lung metastases from other cancers were diagnosed, as well as primary lung cancer in patients with a complaint of dyspnea, which was the most prevalent presenting complaint.

Abi Aad et al. reported that its prevalence is as high as $30 \%$ for the coexistence of cancer and elevated body temperature $(18,19)$. In their study, Escalante et al. [20] found that $10.4 \%$ of the patients with solid tumors and $19.70 \%$ of the patients with hematologic malignancy had fever. In the same study, systolic blood pressure abnormality was found in $14.6 \%$ of the patients, and diastolic blood pressure abnormality was found in $8.7 \%$ of them (20).

The mean body temperature was $36.93 \pm 0.97^{\circ} \mathrm{C}$, the MAP was $84.92 \pm 19.96 \mathrm{mmHg}$, and the mean BPM was $90.46 \pm 19.68$ in patients' series. If patients were dead in the emergency department or were referred to the intensive care unit (ICU) were analyzed separately, the mean body temperature was found $36.05 \pm 0.96^{\circ} \mathrm{C}$, the MAP $69.25 \pm 27.41 \mathrm{mmHg}$, and the mean BPM 93.29 \pm 26.05 . When these data were compared with the patients who were not referred to the ICU and/or those who did not die, a statistically significant difference in terms of MAP and BPM was found: MAP was lower, while BPM was higher in the patients who died or were referred to the ICU.

Escalante et al. (20) found that $33.8 \%$ of the patients who presented to the ED had anemia, $10.97 \%$ had neutropenia, and $7.84 \%$ had hypoalbuminemia at the time of the presentation. In our study, $64.85 \%$ of the patients had anemia, $16.75 \%$ had neutropenia (percentage of the patients with absolute neutropenia: $6.04 \%$ ), and $34.17 \%$ had hypoalbuminemia. When the patients who died in the ED or were referred to the intensive care unit were analyzed separately, it was found that the mean hemoglobin value was $8.07 \pm 4.25 \mathrm{~g} / \mathrm{dl}$, neutrophil count was 7.19 $\pm 5.4(\mathrm{x} 103 / \mathrm{mm} 3)$, thrombocyte count $346.53 \pm 183.04(\mathrm{x} 103 / \mathrm{mm} 3)$, and albumin level was $3.12 \pm 0.52 \mathrm{~g} / \mathrm{dl}$. Decreased hemoglobin level, thrombocyte count, and albumin level caused a statistically significant increase in the intensive care admission and mortality rates; however, no statistically significant relationship was found between neutrophil count and ICU admission and death rates. Additionally, we found that blood urea, creatinine, C-reactive protein, and potassium levels were statistically significantly higher, and serum chloride level was lower in the patients who died or were admitted to the ICU.

Respiratory tract infections frequently occur in cancer patients and are the most important cause of mortality and morbidity in these patients (21). The prevalence of pneumonia reaches as high as $30 \%$, particularly in patients with febrile neutropenia (21, 22). The most common causative agents of pneumonia in oncological patients are $\mathrm{S}$. pneumonia, P. aeruginosa, K. pneumonia, influenza, and parainfluenza viruses. Besides, infections of fungi, such as aspergillus, cause respiratory tract infections in these patients (22). Because urinary system infections are the most frequently observed nosocomial infection, they are also the most commonly occurring complication in hospitalized cancer patients (23).

The most common diagnosis made at the time of the presentation - apart from a primary cancer diagnosis - among the cancer patients we analyzed was pneumonia ( $n=319 ; 20.96 \%)$. Additionally, 120 patients $(7.88 \%)$ had urinary system infection, 64 patients $(4.40 \%)$ had febrile neutropenia, 53 patients (3.48\%) had acute gastroenteritis, 19 (1.259\%) had upper respiratory tract infection, 4 patients $(0.26 \%)$ had soft tissue infection, and one patient $(0.07 \%)$ had shunt infection. All of these patients were received antibiotic treatment. Based on the result of the culture/antibiogram, antibiotics effective against the susceptible bacteria with a spectrum as narrow as possible were preferred in $62.16 \%(n=368)$ of the 592 patients administered antibiotherapy. However, very broad-spectrum antibiotic regimens were administered to 224 patients (37.84\%) with advanced immunosuppression and those with a previous history of multiple hospitalizations.

Acute kidney failure may occur due to renal involvement in cancer or fluid-electrolyte imbalances or as a result of nephrotoxic effects of anti-cancer drugs (24). In the case of acute kidney failure, hemodialysis should be administered without delay. Additionally, interventions to relieve compression and emergency radiotherapy may be required when oncological emergencies such as respiratory failure due to malign pleural effusion, metastatic epidural spinal cord compression, brain edema, or superior vena cava syndrome occur (25, 26). According to the literature, spinal cord compression occurs in 5\% of all cancer patients, and superior vena cava syndrome occurs in $4 \%$ of the patients with lung cancer (26).

We found that 110 patients were diagnosed with acute kidney failure, and hemodialysis was administered to 61 of these patients (55.44\%). Eleven patients required thoracentesis-paracentesis for symptomatic treatment. Emergency radiotherapy combined with intravenous steroid treatment was administered to two patients due to metastatic spinal syndrome and to two patients due to tumor-induced brain edema. 


\section{CONCLUSION}

It is observed that infections are the most common factor that affects morbidity and mortality of malignancy patients. Also, low MAP and high BPM levels are predictors for mortality in the emergency department for malignancy patients. It is found that anemia, hypoalbuminemia, and thrombocytopenia are related to mortality in the ED for cancer patients. We also have to be careful about emergency hemodialysis and spinal cord compression for decreasing mortality and morbidity in the ED.

Based on the results of our study, oncological patients constitute a considerable number of patients presenting to the emergency department. We think that promoting the emergency physicians' insight into and experience oncological emergencies would contribute to decreasing the mortality and morbidity of these patients.

\section{Conflicts of Interest}

All other co-authors have no conflicts of interest.

\section{REFERENCES}

1. Başara BB, Güler C, Eryılmaz Z, Yentür GK, Pulgat E. TC Sağlık Bakanlı̆̆g Sağlık İstatistikleri Yıllı̆̆ı 2013. Sağlı Araştırmaları Genel Müdürlüğü, Sağlık Bakanlığı. Ankara: Sentez Matbaacılık ve Yayıncılık; 2014.

2. Katabathina VS, Restrepo CS, Betancourt Cuellar SL, Riascos RF, Menias CO. Imaging of oncologic emergencies: what every radiologist should know. Radiographics. 2013 Oct;33(6):1533-53. Review

3. Lewis MA, Hendrickson AW, Moynihan TJ. Oncologic emergencies: Pathophysiology, presentation, diagnosis, and treatment. CA Cancer J Clin. 2011 Sep-Oct;61(5):287-314. Review.

4. McCarthy EP, Phillips RS, Zhong Z, Drews RE, Lynn J. Dying with cancer: patients' function, symptoms, and care preferences as death approaches. J Am Geriatr Soc. 2000;48(5 Suppl):S110-21.

5. Suvannasankha A, Chirgwin JM. Role of bone-anabolic agents in the treatment of breast cancer bone metastases. Breast Cancer Res. 2014;16(6):484. Review.

6. Rosner MH, Dalkin AC. Electrolyte disorders associated with cancer. Adv Chronic Kidney Dis. 2014 Jan;21(1):7-17. Review

7. Pi J, Kang Y, Smith M, Earl M, Norigian Z, McBride A. A review in the treatment of oncologic emergencies. J Oncol Pharm Pract. 2015 Oct 6. Doi: 1078155215605661. [Epub ahead of print] Review.

8. Flowers CR, Seidenfeld J, Bow EJ, Karten C, Gleason C, Hawley DK, Kuderer NM, Langston AA, Marr KA, Rolston $\mathrm{KV}$, Ramsey SD. Antimicrobial prophylaxis and outpatient management of fever and neutropenia in adults treated for malignancy: American Society of Clinical Oncology clinical practice guideline. J Clin Oncol 2013; 31:794.

9. Mak KS, Lee LK, Mak RH, Wang S, Pile-Spellman J, Abraham JL, Prigerson HG, Balboni TA. Incidence and treatment patterns in hospitalizations for malignant spinal cord compression in the United States, 1998-2006. Int J Radiat Oncol Biol Phys 2011; 80:824.

10. Swenson KK, Rosa MA, Ritz L, Murray CL, Adlis SA. Recognition and Evaluations of Oncology-Related Symptoms in the Emergency Department. Ann Emerg Med. 1995 Jul;26(1):12-7.

11. Bozdemir N, Eray O, Eken C, Şenol Y, Artaç M, Samur M. Demographics, Clinical Presentation, and Outcome of Cancer Patients Admitting to Emergency Department. Turk J Med Sci. 2009;39: 235-40.

12. Can N, Yolcu Ş, Çetin Beceren NG, Tomruk Ö. Acil Servisimize Başvuran Kanser Hastalarının Sosyodemografik Özelliklerinin ve Acil Başvuları Arasındaki İlişkinin Belirlenmesi. Bozok Tıp Dergisi. 2013;2: 6-11.

13. Yaylacı S, Topuzoğlu A, Karcıŏglu Ö. [Acil Servise Başvuran Kanser Hastalarının Klinik Karakteristikleri ve Bir Yıllık Sağ Kalımlar1]. Int J Hematol Oncol, 2009;19(4): 213-22.

14. Kerrouault E, Denis N, Le Conte P, Dabouis G. [Improving Organization of Care Could Reduce Referrals of Cancer Patients to the Emergency Department]. Presse Med Presse Medicale. 2007;36: 1557-62.

15. Liaw SJ, Bullard MJ, Hu PM, Chen JC, Liao HC. Rates and Causes of Emergency Department Revisits Within 72 Hours. J Formos Med Assoc 1999;98(6): 422-5.

16. Kılıçarslan İ, Bozan H, Oktay C, Göksu E. Türkiye'de Acil Servise Başvuran Hastaların Demografik Özellikleri. Türkiye Acil Tip Dergisi,2005;5(1): 5-13.

17. Koçak S, Ertekin B, Polat M, Girişgin S, Kara H. Onkolojik Hastaların Acile Başvuru Nedenleri. Sakarya Medical Journal, 2012;2(1): 16-20.

18. Abi Aad S, Pierce M, Barmaimon G, Farhat FS, Benjo A, Mouhayar E. Hypertension induced by chemotherapeutic and immunosuppressive agents: a new challenge. Crit Rev Oncol Hematol. 2015 Jan;93(1):28-35. Review.

19. Moussaid Y, Bertaux M, Chargari C, Helissey C, Le Moulec S, Errihani H, Vedrine L. [Fever and cancer: components of diagnosis for optimal management]. Rev Med Interne. 2013 Sep;34(9):545-52. Review

20. Escalante CP, Manzullo EF, Lam TP, Ensor JE, Valdres RU, Wang XS. Fatigue and its risk factors in cancer patients who seek emergency care. J Pain Symptom Manage. 2008 Oct;36(4):358-66.

21. Anderson EJ. Respiratory infections. Cancer Treat Res. 2014;161:203-36.

22. Evans SE, Ost DE. Pneumonia in the neutropenic cancer patient. Curr Opin Pulm Med. 2015 May;21(3):260-71.

23. Wada K, Kumon H. [Managements of urinary catheterization and urinary tract infection in cancer patients]. Gan To Kagaku Ryoho. 2012 Feb;39(2):169-73.

24. Endicott M. Oncologic emergencies. Clin Tech Small Anim Pract. 2003 May;18(2):127-30. Review.

25. Aydin Y, Turkyilmaz A, Intepe YS, Eroglu A. Malignant pleural effusions: appropriate treatment approaches. Eurasian J Med. 2009 Dec;41(3):186-93. Review.

26. Walji N, Chan AK, Peake DR. Common acute oncological emergencies: diagnosis, investigation, and management. Postgrad Med J. 2008 Aug;84(994):418-27. Review. 